\title{
PENGARUH PENDIDIKAN KESEHATAN PERTOLONGAN PERTAMA TERSEDAK DENGAN GOOGLE FORM DAN PHANTOM PADA ORANG TUA DI TK TAMAN SUKARIA TERHADAP KEMAMPUAN KELUARGA
}

\section{EFFECT OF FIRST AID HEALTH EDUCATION IN CHARACTER WITH GOOGLE FORM AND PHANTOM IN CHILDREN'S PRE-SCHOOL IN TAMAN SUKARIA KINDERGROUND ON FAMILY CAPABILITY}

\author{
Endang Suartini, Kusniawati \\ Poltekkes Kemenkes Banten \\ Korespondensi: endingkalbar@gmail.com
}

\begin{abstract}
Choking is an emergency condition that must be quickly dealt with. Because, if left too long the body can experience a lack of oxygen (hypoxia) and result in death. In the United States in 2010, data on 710 cases of choking occurred in children under 4 years of age. With an incidence proportion of $11.6 \%$ occurring in children under 1 year of age, $36.2 \%$ occurring in children aged 1 to 2 years, and 29.4\% occurring in children aged 2 years (American Academy of Pediatrics; AAP, 2010). One way to increase knowledge about handling choking is to provide health education. This relates to the role of nurses as educators or educators or provides counseling. The purpose of knowing the difference in the average family's ability to use phantoms before and after health education was carried out on the handling of choking in parents at Taman Sukaria Kindergarten. The research method uses Pre Experimental with one group pretest-posttest design. The results showed there were no significant differences between parents' knowledge before and after choking first aid health education namely P-Value 0.323 ( $>\alpha$ 0.05), while there were significant differences between parental skills before and after health education. The first choke is P-value 0,000 $(<\alpha 0,05)$. Suggestions There is an effect of choking first aid health education with Google Form and Phantom on parents at Taman Sukaria Kindergarten on family skills so that it is hoped that this research can be used as a competency module for parents to do the first treatment of choking.
\end{abstract}

Keywords: Health Education, Skills, Choking

\begin{abstract}
ABSTRAK
Tersedak merupakan kondisi gawat darurat yang harus cepat ditangani. Karena, bila dibiarkan terlalu lama tubuh bisa mengalami kekurangan oksigen (hipoksia) dan mengakibatkan kematian. Di Amerika Serikat pada tahun 2010 didapatkan data 710 kasus tersedak terjadi pada anak usia dibawah 4 tahun. Dengan persentase kejadian 11,6\% terjadi pada anak usia dibawah 1 tahun, 36,2\% terjadi pada anak usia 1 hingga 2 tahun dan 29,4\% terjadi pada anak usia 2 hingga 4 tahun (American Academy of Pediatric; AAP, 2010). Salah satu untuk meningkatkan pengetahuan tentang penanganan tersedak yaitu memberikan pendidikan kesehatan. Hal ini berkaitan dengan peran perawat sebagai educator atau pendidik atau memberikan penyuluhan. Tujuan mengetahui perbedaan rerata kemampuan keluarga
\end{abstract}


menggunakan phantom sebelum dan sesudah dilakukan pendidikan kesehatan tentang penanganan tersedak pada orang tua di TK Taman Sukaria. Metode Penelitian menggunakan Pre Eksperimental dengan one group pretest posttest design. Hasil Penelitian menunjukan tidak ada perbedaan yang signifikan antara pengetahuan orang tua sebelum dan sesudah dilakukan pendidikan kesehatan pertolongan pertama tersedak yakni nilai P Value 0,323 (> $\alpha$ $0,05)$, sedangkan terdapat perbedaan yang signifikan antara keterampilan orang tua sebelum dan sesudah dilakukan pendidikan kesehatan pertolongan pertama tersedak yakni nilai $\mathrm{P}$ Value $0,000(<\alpha 0,05)$. Saran Terdapat pengaruh pendidikan kesehatan pertolongan pertama tersedak dengan Google Form dan Phantom pada Orang tua di TK Taman Sukaria terhadap keterampilan keluarga sehingga diharapkan penelitian ini dapat dijadikan modul kompetensi untuk orang tua melakukan penanganan pertama tersedak.

Kata Kunci : Pendidikan Kesehatan, Keterampilan, Tersedak

\section{PENDAHULUAN}

Tersedak merupakan kondisi gawat darurat yang harus cepat ditangani. Karena, bila dibiarkan terlalu lama tubuh bisa mengalami kekurangan oksigen (hipoksia) dan dapat mengakibatkan kematian. Tersedak muncul ketika suatu benda menyangkut di kerongkongan dan menghalangi sebagian jalan udara (Saubers, 2011 dalam Rika Puji R., 2014). Tersedak adalah penyebab utama dari morbiditas dan mortalitas anak, khususnya pada anak usia 3 tahun atau di bawah 3 tahun. Makanan, balon, koin dan minuman adalah penyebab tersedak paling sering yang dapat menimbulkan luka bahkan kematian. Beberapa jenis, bentuk dan ukuran dari makanan dan minuman dapat berpotensi untuk meningkatkan kejadian tersedak pada anak (American Academy of Pediatrics, 2010).
Menurut WHO (2011) dalam jurnal Putri Wulandari (2018), sekitar 17.537 kasus tersedak paling sering terjadi pada anak usia toddler (12-36 bulan). Adapun penyebab tersedak dari kejadian ini adalah $59,5 \%$ karena makanan, $31,4 \%$ tersedak karena benda asing, dan sebesar 9,1\% penyebab tersedak tidak diketahui. Di Amerika Serikat pada tahun 2010 didapatkan data 710 kasus tersedak terjadi pada anak usia dibawah 4 tahun. Dengan persentase kejadian $11,6 \%$ terjadi pada anak usia dibawah 1 tahun, 36,2\% terjadi pada anak usia 1 hingga 2 tahun dan 29,4\% terjadi pada anak usia 2 hingga 4 tahun (American Academy of Pediatric; AAP, 2010). Berdasarkan penelitian yang diterbitkan dalam Journal Pediatric pada Juli 2013, menunjukkan bahwa sekitar 12.435 anak-anak atau 34 anak per hari dibawa ke ruang gawat darurat karena tersedak. Anak usia empat tahun paling 
tinggi persentasenya yaitu $62 \%$, dan anak usia dibawah satu tahun sebesar $38 \%$. Urutan teratas makanan yang dapat beresiko menimbulkan tersedak adalah permen yang bertekstur keras (hard candy) $15,5 \%$, permen lainnya seperti permen lunak dan permen karet menempati urutan kedua dengan angka kejadian tersedak 12,8\%., makanan lainnya adalah daging (bukan hotdog) dan tulang dengan masingmasing persentase adalah $12,20 \%$ dan $12 \%$. Di Indonesia sendiri, menurut data yang diperoleh dari RSUD dr Harjono Ponorogo Kota Semarang tahun 2009 ditemukan kasus tersedak sebanyak 157 orang. Kasus tersedak ini semakin menurun pada tahun 2010 menjadi 112 orang.

Pada dasarnya, kasus tersedak ini dapat ditangani oleh siapa saja, terutama keluarga yang memiliki anak balita. Keterampilan terhadap pertolongan pertama pada anak merupakan langkah selanjutnya yang harus dilakukan oleh orangtua atau pengasuh. Karena, keterampilan yang cepat dari orangtua atau pengasuh sangat berpengaruh terhadap keselamatan anak. Pengetahuan juga menjadi hal yang penting bagi individu yang memiliki anak balita. Kurangnya pengetahuan akan berdampak pada perilaku orang tua atau pengasuh dalam menangani tersedak pada anak. Bila perilaku dalam penanganan tersedak pada anak benar, maka anak akan terhindar dari ancaman kematian, dan begitu pun sebaliknya. Adapun salah satu untuk meningkatkan pengetahuan tentang penanganan tersedak yaitu dengan memberikan pendidikan kesehatan. Hal ini berkaitan dengan peran perawat sebagai educator atau pendidik. Perawat sebagai pendidik dapat memberikan penyuluhan sehingga terjadi perubahan perilaku dari klien setelah dilakukan pendidikan kesehatan.

Berdasarkan penelitian yang dilakukan oleh Rika Puji Rahayu (2014) tentang pengaruh pendidikan kesehatan terhadap tingkat pengetahuan orang tua dalam menangani anak tersedak di Desa Kedungsoka Pulo Ampel Serang Banten dengan jumlah responden 51 orang didapatkan hasil analisa bivariat menunjukkan bahwa tingkat pengetahuan orang tua sebelum diberikan pendidikan kesehatan adalah cukup sebanyak 56,9\% dan hasil analisis data setelah diberikan pendidikan kesehatan tingkat pengetahuan orang tua adalah baik sebanyak 41,2\%. Analisa bivariat dengan menggunakan uji Wilcoxon Signed Rank Test diperoleh $p$ value sebesar $0,000<\alpha 0,005$.

Sekolah Taman Kanak-Kanak Taman Sukaria Kota Tangerang dengan mempunyai siswa sebanyak 32 anak usia 5 
tahun - 6 tahun.. Pada survei awal penelitian yang dilakukan pada bulan Febuari 2019, menurut hasil wawancara yang peneliti lakukan pada salah satu guru sekolah tersebut yaitu tidak ada siswa mengalami tersedak dan belum ada yang memberikan pendidikan kesehatan tentang penanganan tersedak pada orang tua. Berdasarkan hasil wawancara dengan 10 ibu, didapatkan data awal dari 8 orang ibu yang diwawancarai yang mengatakan bahwa mereka mengetahui tentang tersedak, namun pada saat ditanya tentang pertolongan pertama jika anak tersedak, 1 dari 10 ibu mengatakan akan menepuknepuk punggung anak, 2 dari $10 \mathrm{ibu}$ mengatakan akan memberikan minum air putih yang banyak kepada anak agar benda asing tersebut dapat masuk ke kerongkongan, dan 1 dari 10 ibu mengatakan akan menepuk-nepuk pundak anak dan memberikan minum air putih kepada anak.

Tujuan untuk Menganalisis adanya pengaruh Pendidkan Kesehatan Pertolongan Pertama Tersadak dengan Google Form Dan Phantom Pada Orang tua Di TK Taman Sukaria Terhadap Kemampuan Keluarga. Adapun tujuan khusus meliputi : mengetahui rerata skore pengetahuan dan kemampuan keluarga menggunakan phantom dalam penanganan tersedak pada orang tua sebelum diberikan pendidikan kesehatan, mengetahui rerata skore pengetahuan dan kemampuan keluarga menggunakan phantom dalam penanganan tersedak pada orang tua sesudah diberikan pendidikan kesehatan, mengetahui perbedaan rerata kemampuan keluarga menggunakan phantom sebelum dan sesudah dilakukan pendidikan kesehatan tentang penanganan tersedak pada orang tua di TK Taman Sukaria.

\section{METODE}

Penelitian ini merupakan jenis Pre Eksperimental dengan one group pretest posttest design. Penelitian ini tidak menggunakan kelompok pembanding namun sudah menggunakan tes awal sehingga banyak efek atau pengaruh pemberian edukasi pertolongan pertama dapat diketahui secara pasti. Dalam penelitian ini, subyek penelitian terlebih dahulu diberikan tes awal (prestest) untuk mengetahui sejauh mana kemampuan dan keterampilan awal responden sebelum diberikan Pendidikan Kesehatan pertolongan pertama tersedak, hanya melihat Google Form saja Setelah diberikan tes awal, selanjutnya kepada responden tersebut diberikan perlakuan, yaitu pendidika kesehatan pertolongan pertama tersedak dan simulasi dengan pantom. Setelah selesai diberikan 
pendidikan kesehatan pertolongan pertama tersedak dan simulasi dengan panthom, selanjutnya kepada seluruh responden diberikan tes akhir (posttest) untuk mengetahui sejauh mana keluarga mampu menggunakan phantom dalam penanganan tersedak pada anak .

Populasi dari penelitian ini adalah seluruh orang tua / keluarga yang memiliki anak di TK Taman Sukaria Kota Tangerang dengan jumlah sampel sebanyak 41 responden. Uji statistik yang dipilih tergantung dari skala variabel independen dan dependen yang digunakan. Oleh karena itu, peneliti menggunakan uji statistik yaitu uji wilkoxon.

\section{HASIL DAN PEMBAHASAN}

a. Distribusi Frekuensi Pengetahuan Ibu tentang Penanganan Tersedak pada Anak

Tabel 1. Rerata Skor Pengetahuan Ibu Sebelum dan Sesudah Pendidikan Kesehatan tentang Penanganan Tersedak pada Anak

\begin{tabular}{lccc}
\hline Variabel & Mean & SD & $\begin{array}{c}\text { Min - } \\
\text { Max }\end{array}$ \\
\hline $\begin{array}{l}\text { Pengetahuan } \\
\text { Sebelum }\end{array}$ & 7,7 & 1,5 & $5-10$ \\
$\begin{array}{l}\text { Sesudah } \\
\text { Perbedaan }\end{array}$ & 8,0 & & \\
\hline
\end{tabular}

Tabel diatas menunjukkan bahwa rerata skor Pre-test pengetahuan adalah 7,7 dengan standar deviasi 1,5 dan mengalami peningkatan 0,3 poin pada rerata skor
Post-test pengetahuan menjadi 8,0 dengan standar deviasi 1,0. Hasil yang diperoleh menggambarkan adanya peningkatan rerata pengetahuan ibu antara sebelum dan sesudah dilakukan pendidikan kesehatan tentang penanganan tersedak pada anak

b. Kemampuan Ibu tentang Penanganan Tersedak pada Anak Tabel. 2 Rerata Skor Keterampilan Ibu Sebelum dan Sesudah Pendidikan Kesehatan tentang Penanganan Tersedak pada Anak

\begin{tabular}{lccc}
\hline Variabel & Mean & SD & Min - Max \\
\hline Keterampilan & 4,5 & 2,6 & $0-10$ \\
Sebelum & 9,5 & 1,4 & $4-10$ \\
Sesudah & 5 & & \\
Perbedaan & & &
\end{tabular}

Tabel diatas menunjukkan bahwa rerata skor Pre-test keterampilan adalah 4,5 dengan standar deviasi 2,6 dan mengalami peningkatan 5 poin pada rerata skor Posttest pengetahuan menjadi 9,5 dengan standar deviasi 1,4. Hasil yang diperoleh menggambarkan adanya peningkatan rerata keterampilan ibu antara sebelum dan sesudah dilakukan pendidikan kesehatan tentang penanganan tersedak pada anak.

Tabel 3. Rerata Perubahan Skor Pengetahuan Ibu Sebelum dan Sesudah Pendidikan Kesehatan tentang Penanganan Tersedak pada Anak

\begin{tabular}{lccccc}
\hline \multicolumn{1}{c}{ Variabel } & Mean & SD & Df & Z & $\begin{array}{c}\text { P Value } \\
\text { (Sig) }\end{array}$ \\
\hline $\begin{array}{l}\text { Pengetahuan } \\
\text { Pre-test }\end{array}$ & 7,7 & 1,5 & 40 & - & \\
$\begin{array}{l}\text { Pengetahuan } \\
\begin{array}{l}\text { Post-test } \\
\text { Pent }\end{array}\end{array}$ & 8 & 1,0 & 40 & 0,989 & 0,323 \\
\hline
\end{tabular}


Tabel diatas, diperoleh nilai $P$ Value (Sig) sebesar 0,323 artinya pemberian pendidikan kesehatan tidak berpengaruh terhadap pengetahuan ibu tentang penanganan tersedak pada anak.

Tabel 4. Perbandingan Rerata Perubahan Skor Keterampilan Ibu Sebelum dan Sesudah Pendidikan Kesehatan tentang Penanganan Tersedak pada Anak

\begin{tabular}{llllll}
\hline Variabel & Mean & SD & Df & Z & $\begin{array}{c}\text { P Value } \\
\text { (Sig) }\end{array}$ \\
\hline $\begin{array}{l}\text { Skor } \\
\text { Keterampila } \\
\text { n Pre-test }\end{array}$ & 4,5 & 2,6 & $\mathbf{4 0}$ & - & \\
\cline { 1 - 4 } $\begin{array}{l}\text { Skor } \\
\begin{array}{l}\text { Keterampila } \\
\text { n Post-test }\end{array}\end{array}$ & 9,5 & 1,4 & 40 & 5,561 & 0,000 \\
\hline
\end{tabular}

Berdasarkan Tabel 4 diperoleh nilai $P$ Value (Sig) sebesar 0,000 dengan demikian pemberian pendidikan kesehatan dapat berpengaruh terhadap keterampilan ibu tentang penanganan tersedak pada anak.

c. Keterampilan Ibu tentang Tabel 5. Rerata Skor Keterampilan Ibu Sebelum dan Sesudah Pendidikan Kesehatan tentang Penanganan Tersedak pada Anak Di TK Taman Sukaria

\begin{tabular}{lccc}
\hline Variabel & Mean & SD & Min - Max \\
\hline $\begin{array}{l}\text { Keterampilan } \\
\text { Sebelum }\end{array}$ & 4,5 & & \\
Sesudah & 9,5 & 2,6 & $0-10$ \\
& 5 & 1,4 & $4-10$ \\
Perbedaan & 5 & & \\
\hline
\end{tabular}

Tabel diatas menunjukkan bahwa rerata skor Pre-test keterampilan adalah 4,5 dengan standar deviasi 2,6 dan mengalami peningkatan 5 poin pada rerata skor Post- test pengetahuan menjadi 9,5 dengan standar deviasi 1,4. Hasil yang diperoleh menggambarkan adanya peningkatan rerata keterampilan ibu antara sebelum dan sesudah dilakukan pendidikan kesehatan tentang penanganan tersedak pada anak.

\section{Rerata Skor Pengetahuan Keluarga Menggunakan Google Form dalam Penanganan Tersedak pada Orang Tua \\ Hasil penelitian tentang distribusi} pengetahuan orang tua tentang pertolongan pertama tersedak menunjukkan adanya peningkatan skor pengetahuan sesudah dilakukan pendidikan kesehatan pertolongan pertama tersedak. Hal ini dibuktikan dengan adanya peningkatan rerata skor Pre-test pengetahuan 7,7 dan meningkat 0,3 poin pada rerata skor Posttest pengetahuan menjadi 8,0

Hal tersebut sesuai dengan penelitian yang dilakukan oleh Dwi Sumarningsih (2015), yang menunjukkan peningkatan skor pengetahuan sesudah dilakukan edukasi keluarga, terjadi peningkatan skor pengetahuan antara sebelum dan sesudah dilakukan edukasi keluarga dengan rerata skor Pre-test 15,95 dan mengalami peningkatan 15,85 poin menjadi 31,80 pada rerata skor Post-test. Pengetahuan seseorang bisa meningkat jika didukung oleh berbagai faktor, salah satunya adalah ketersediaan alat atau fasilitas yang cukup seperti informasi yang dibutuhkan sesuai 
dengan masalah yang responden belum ketahui. Pemilihan metode pendidikan kesehatan akan berpengaruh terhadap keberhasilan penelitian. Pada penelitian ini menggunakan mobile application dikarenakan jumlah responden dalam penelitian ini cukup besar dan memiliki latar belakang pendidikan yang berbeda serta adanya interaksi antara peneliti dengan responden.

\section{Rerata Skor Kemampuan Keluarga Menggunakan Phantom dalam Penanganan Tersedak pada anak}

Hasil penelitian tentang dsitribusi keterampilan orang tua dalam pertolongan pertama tersedak menunjukkan adanya peningkatan skor keterampilan sesudah dilakukan pendidikan kesehatan pertolongan pertama tersedak, dengan rerata skor Pre-test pengetahuan 4,5 dan meningkat 5 poin pada rerata skor Post-test pengetahuan menjadi 9,5.Penelitian yang dilakukan oleh Dwi Sumarningsih (2015) menemukan hal yang sama bahwa perubahan skor keterampilan antara sebelum dan sesudah dilakukan edukasi keluarga dengan rerata skor Pre-test 3,4 dan mengalami peningkatan sebesar 5,1 poin menjadi 8,5 pada rerata skor Post-test. Peningkatan skor keterampilan ini terjadi karena dalam pendidikan kesehatan dengan metode pendidikan kesehatan yang digunakan juga berpengaruh dalam meningkatkan pengetahuan seperti demonstrasi, pada penelitian ini informasi yang diberikan dengan apa yang dibutuhkan responden untuk melakukan pencegahan tersedak yaitu informasi yang berisi pertolongan pertama tersedak. Selain memberikan informasi dengan metode ceramah, informasi juga diberikan dengan metode demonstrasi menggunakan phantom bayi dan dengan adanya demonstrasi akan menghilangkan kejenuhan pada responden yang hanya menerima informasi dengan metode ceramah saja, karena responden menggunakan indera penglihatan, pendengaran, dan memacu daya ingat responden. Semakin banyak alat indera yang digunakan untuk menerima dan mengolah informasi maka semakin besar informasi tersebut dimengerti dan selalu diingat.

Hal tersebut sesuai dengan pendapat yang diungkapkan Machfoedz dkk (2005) dalam Rohmayana (2011), menyatakan bahwa daya tangkap terhadap informasi yang sangat dipengaruhi oleh kefektifan fungsi indera untuk menangkap stimulus yang diberikan sehingga dapat dicerna dengan baik menjadi suatu informasi, semakin banyak jumlah indera yang terlibat dalam suatu proses penerimaan informasi maka akan semakin besar daya tangkap terhadap stimulus tersebut. 
Perbedaan Rerata Pengetahuan

Keluarga Menggunakan Google Form Sebelum dan Sesudah Dilakukan Pendidikan Kesehatan Tentang Penanganan Tersedak

Hasil analisa data dalam penelitian ini, diketahui tidak terdapat pengaruh yang signifikan (P value 0,323$)$ setelah dilakukan pendidikan kesehatan dimana terjadi peningkatan skor pengetahuan antara Pretest dan Post-test. Dalam Kamus Umum Besar Indonesia oleh Poerwadarmita (2011) pengetahuan didefinisikan sebagai segala sesuatu yang diketahui atau akan diketahui yang berkenan dengan suatu hal. Dalam hal ini yaitu pengetahuan keluarga tentang penanganan tersedak pada balita yang mengalami peningkatan setelah dilakukan pendidikan kesehatan. Hasil serupa didapatkan dalam penelitian yang dilakukan oleh Panji N, Prasetio (2019) yang menyimpulkan bahwa pendidikan kesehatan dengan metode Media aplikasi dapat meningkatkan skor pengetahuan secara signifikan $(P$ value 0,000$)$. Begitu juga dengan penelitian yang dilakukan oleh Rika (2014) yang mengalami peningkatan signifikan $(P$ value 0,000$)$ pada skor pengetahuan setelah dilakukan pendidikan kesehatan dengan metode ceramah. Peningkatan pengetahuan pada keluarga dalam penelitian ini terjadi oleh karena pesan atau informasi yang diberikan tersampaikan dengan baik. Yang mana sebelum melakukan pendidikan kesehatan terlebih dahulu membuat SAP (Satuan Acara Penyuluhan) sebagai strategi pelaksanaan pendidikan kesehatan dengan metode Mobile Aplication dan demonstrasi dapat lebih efektif. Sebagaimana dengan gagasan (Notoatmodjo, 2012) yang menyatakan bahwa pendidikan kesehatan akan berhasil bila pesan atau informasi yang akan disampikan kepada komunikan disusun dengan terencana, efektif dan efisien dengan metoda yang tepat.

Saat dilakukan pendidikan kesehatan, peneliti memberikan informasi atau memberikan perintah dalam memberikan pesan atau informasi kepada keluarga akan tetapi juga berkomunikasi efektif selama kegiatan didalam pendidikan kesehatan, sesuai dengan gagasan WHO dan Depkes RI (2009) yang meliputi: mengamati respon, memberi informasi dan berdiskusi, memberi contoh, meminta responden mempraktikannya dan mengecek pemahaman dengan meminta reponden mengulang teknik yang telah diberikan dan dengan kata-kata sendiri. Selain itu dalam pelaksanaannya, pendidikan kesehatan dilakukan peneliti dengan menggunakan media Google Form, yaitu, saat memberikan informasi dan diskusi, alat peraga didalam demonstrasi yang kemudian 
meminta responden untuk mempraktikannya kembali,

Peningkatan pengetahuan pun akhirnya terjadi karena adanya faktor yang mempermudah yakni dengan adanya penggunaan media didalam pendidikan kesehatan dan pengulangan informasi yang diberikan saat berdiskusi. Teori pendidikan pun menyatakan bahwa belajar yang paling baik dan mudah adalah dengan menggunakan panca indera sebanyak mungkin, yang untuk maksud tersebut adalah dengan menggunakan media pendidikan kesehatan. Hal ini sesuai dengan gagasan Notoatmodjo (2012), mengenai manfaat media pendidikan kesehatan yaitu dapat membantu dalam mengatasi banyak hambatan dalam pemahaman, mempermudah penyampaian dan penerimaan informasi kesehatan, mendorong keinginan untuk mengetahui, kemudian lebih mendalami dan akhirnya mendapatkna pengertian yang lebih baik serta membantu menegakkan pengertian yang diperoleh didalam menerima sesuatu yang baru.

Dalam penelitian ini ditemukan adanya beberapa responden yang masih memiliki pengetahuan dibawah rerata. Hal ini di latar belakangi karena respon setiap individu yang berbeda-beda, hal ini bisa terjadi karena saat diberikan materi responden tersebut tidak memperhatikan dengan benar dan juga dapat dikarenakan faktor lingkungan sekitar misalnya anak menangis dan aktif berlari, tetapi semua hambatan yang dapat mengganggu konsentrasi responden dapat diatasi, hal ini dapat dibuktikan dari tingkat pengetahuan yang mengalami peningkatan antara sebelum dan sesudah diberikan pendidikan kesehatan.

Berdasarkan hasil penelitian di atas dapat disimpulkan bahwa peran pendidikan kesehatan diharapkan menjadi salah satu intervensi kesehatan yang dapat meningkatkan pengetahuan keluarga yang memiliki balita untuk dapat melakukan penanganan tersedak pada balita sehingga dapat menurunkan angka kematian balita akibat penyebab yang dapat dicegah

\section{Perbedaan Rerata Kemampuan Keluarga Menggunakan Phantom Sebelum dan Sesudah Dilakukan Pendidikan Kesehatan Tentang Penanganan Tersedak}

Hasil analisa data dalam penelitian ini, diketahui terdapat pengaruh yang signifikan $(P$ value 0,000$)$ setelah dilakukan pendidikan kesehatan dimana terjadi peningkatan skor keterampilan antara Pretest dan Post-test. Peningkatan keterampilan responden dalam melakukan penanganan tersedak dapat dipengaruhi oleh intervensi pendidikan kesehatan tentang pertolongan pertama tersedak. 
Kemampuan keluarga pada penelitian ini dilakukan dengan membuat kelompok kecil dan dengan cara demonstrasi pada phantom bayi, sehingga responden lebih fokus dan konsentrasi dalam memperhatikan demonstrasi penanganan tersedak pada balita yang diberikan pada saat intervensi. Peningkatan juga dapat dipengaruhi oleh waktu antara Pre-test dan Post-test, karena pada penelitian ini Pre-test dan Post-test dilakukan pada hari yang sama sehingga responden masih memiliki memori yang cukup kuat untuk mengingat materi demonstrasi penanganan tersedak pada balita yang diberikan.

Demonstrasi melibatkan lebih dari satu indera seperti indera penglihatan, pendengaran, dan juga koordinasi gerak sehingga memori untuk menyimpan informasi lebih kuat. Hasil penelitian yang mendukung adalah penelitian Pracita (2011) bahwa pendidikan kesehatan dengan menggunakan metode demonstrasi memiliki pengaruh positif terhadap peningkatan keterampilan.

\section{SIMPULAN}

Berdasarkan hasil penelitian dapat disimpulkan sebagai berikut :

1. Rerata skore pengetahuan antara sebelum dan sesudah dilakukan pendidikan kesehatan pada orang tua mengalami peningkatan yang signifikan dengan skor minimal 6 sebanyak 1 orang dan nilai maksimal 10 sebanyak 4 orang, dengan skor rerata yang diperoleh 8,0 naik 0,3 poin dari skor pengetahuan sebelum dilakukan pendidikan kesehatan.

2. Rerata skore keterampilan antara sebelum dan sesudah dilakukan pendidikan kesehatan pada orang tua mengalami peningkatan yang signifikan dengan skor minimal 4 sebanyak 2 orang dan nilai maksimal 10 sebanyak 32 orang, dengan skor rerata yang diperoleh 9,5 naik 5 poin dari skor keterampilan sebelum dilakukan pendidikan kesehatan.

3. Tidak ada perbedaan yang signifikan antara pengetahuan orang tua sebelum dan sesudah dilakukan pendidikan kesehatan pertolongan pertama tersedak. Tidak terdapat pengaruh pendidikan kesehatan pertolongan pertama tersedak dengan Google Form dan phantom pada orang tua di TK Taman Sukaria terhadap pengetahuan keluarga

4. Ada perbedaan yang signifikan antara keterampilan orang tua sebelum dan sesudah dilakukan pendidikan kesehatan pertolongan pertama tersedak. Nilai $\mathrm{Z}$ hitung $=-5,561$ dan diperoleh nilai $\mathrm{P}$ value (sig) sebesar 0,000 karena $\mathrm{P}$ value $($ sig $)<\alpha(0,05)$, dengan demikian, hasil 
penelitian ini adalah terdapat pengaruh pendidikan kesehatan pertolongan pertama tersedak dengan Google Form dan phantom pada orang tua di TK Taman Sukaria terhadap keterampilan keluarga.

\section{UCAPAN TERIMA KASIH}

Ucapan terima kasih disampaikan kepada Poltekkes Kemenkes Banten telah memfasilitasi kegiatan penelitian ini.

\section{DAFTAR PUSTAKA}

Darmawan, Anthony Christian. 2016. Kiat Mengatasi Tersedak pada Anak. Ikatan Dokter Anak Indonesia. http://www.idai.or.id/artikel/klinik/kelu han-anak/kiat-mengatasi-tersedak-padaanak. Diperoleh tanggal 18 Januari 2019.

Edwina. 2010. Pertolongan Pertama dan Bedah Klinis. Jakarta: EGC

Fitriani, Sinta. 2011. Promosi Kesehatan. Yogyakarta: Graha Ilmu

Hidayat, Aziz Alimul. 2017. Metodologi Penelitian Keperawatan dan Kesehatan. Jakarta: Salemba Medika Notoatmodjo, Soekidjo. 2007. Kesehatan Masyarakat: Ilmu dan Kiat. Jakarta: PT. Rineka Cipta
Notoatmodjo, Soekidjo. 2012. Promosi Kesehatan dan Perilaku Kesehatan. Jakarta: PT. Rineka Cipta

Notoatmodjo, Soekidjo. 2018. Kesehatan Masyarakat: Ilmu dan Kiat. Jakarta: PT. Rineka Cipta

Nursalam. 2017. Metodologi Penelitian Ilmu Keperawatan: Pendekatan Praktis Edisi 4. Jakarta: Salemba Medika

Pusponegoro, A.D., et al. 2018. Basic Trauma Life Support \& Basic Cardiac Life Support Edisi ketujuh. Jakarta: Yayasan Ambulans Gawat Darurat 118 Rahayu, Rika Puji. 2014. Skripsi. Pengaruh Pendidikan Kesehatan Terhadap Pengetahuan Orang Tua Dalam Menangani Anak Tersedak di Desa Kedungsoka Pulo Ampel Serang Banten. Program Studi Ilmu Keperawatan. Stikes Jenderal Achmad Yani, Yogyakarta. http://repository.unjaaya.ac.id/957/.

Diperoleh tanggal 04 Februari 2019. Somasetia, Dadang Hudaya. 2017. Yang Harus Dilakukan Jika Anak Tersedak. Ikatan Dokter Anak Indonesia. http://www.idai.or.id/artikel/klinik/kelu han-anak/yang-harus-dilakukan-jikaanak-tersedak. Diperoleh tanggal 18 Januari 2019.

Sumarningsih, Dwi. 2015. Skripsi. Pengaruh Edukasi Keluarga Tentang 
Pencegahan dan Penanganan Tersedak

Pada Anak Terhadap Pengetahuan dan

Keterampilan Keluarga Dusun Ngebel

RT.09 Taman Tirto Kasihan Bantul.

Program Studi Ilmu Keperawatan.

STIKES 'Aisyiyah, Yogyakarta.

http://digilib.unisayogya.ac.id/201/1/N

ASKAH\%20PUBLIKASI.pdf

diperoleh tanggal 01 Februari 2019.

TIM Bantuan Medis BEM IKM FKUI.

2015. Modul Bantuan Hidup Dasar dan

Penanganan Tersedak. Universitas

Indonesia, Depok.

http://tbmfkui.org/wp-

content/uploads/2015/08/Modul-

Bantuan-Hidup-Dasar-dan-Penanganan-

Tersedak-TBM-BEM-IKM-FKUI.pdf.

Diakses tanggal 19 Januari 2019. 